\title{
RESPON PERTUMBUHAN DAN PRODUKSI TANAMAN BAWANG MERAH (Allium ascalonicum L.) TERHADAP PEMBERIAN EKSTRAK KULIT PISANG KEPOK DAN PUPUK KANDANG AYAM
}

\author{
Response The Growth And Production Of Onion Plant \\ (Allium ascalonicum L.) On The Extract Of Kepok Banana Peel And Chicken Manure
}

\author{
Risnawati*), Dartius, Mentari Oniva Mulya, Bobi Setiawan \\ Program Studi Agroteknoogi. Fakultas Pertanian. Universitas Muhammadiyah sumatera Utara. \\ J1. Kapten Mukhtar Basri No.3, Glugur Darat II, Medan Timur, Kota Medan Sumatera Utara 20238, \\ Indonesia \\ (*Corresponding author: risnawati@umsu.ac.id
}

\begin{abstract}
ABSTRAK
Penelitian ini bertujuan untuk mengetahui pengaruh pemberian ekstrak kulit pisang kepok dan pupuk kandang ayam terhadap pertumbuhan dan hasil tanaman bawang merah. Penelitian ini dilaksanakan di Lahan Percobaan Balai Benih Induk jalan Karya Jaya No. 22 f Kecamatan Medan Johor dengan ketinggian tempat \pm 27 mdpl. Analisis data menggunakan Rancangan Acak Kelompok (RAK) faktorial dengan 2 faktor, faktor pertama ekstrak kulit pisang kepok dengan 4 taraf yaitu $\mathrm{P}_{0}$ : tanpa perlakuan (Kontrol), $\mathrm{P}_{1}: 60 \mathrm{ml} /$ polybag, $\mathrm{K}_{2}: 120 \mathrm{ml} /$ polybag, $\mathrm{K}_{3}: 180 \mathrm{ml} /$ polybag dan faktor kedua pemberian pupuk kandang ayam dengan 4 taraf yaitu $\mathrm{K}_{0}$ : tanpa perlakuan (Kontrol), $\mathrm{K}_{1}: 60 \mathrm{~g} / \mathrm{polybag}$, $\mathrm{K}_{2}: 120 \mathrm{~g} /$ polybag, $\mathrm{S}_{3}: 180 \mathrm{~g} /$ polybag. Jika $\mathrm{F}$ hitung lebih besar dari $\mathrm{F}$ tabel 5\% maka dilakukan uji lanjut dengan menggunakan uji DMRT (Duncan's Multiple Range Test) pada taraf nyata 5\%. Ekstrak kulit pisang kepok dan kombinasi ekstrak kulit pisang dengan pupuk kandang ayam tidak memberikan pengaruh yang nyata. Tanaman bawang merah respon terhadap pemberian pupuk kandang ayam dan berpengaruh nyata terhadap tinggi tanaman, jumlah daun, bobot basah umbi per plot, bobot kering umbi per plot dan produksi tanaman sampel.
\end{abstract}

Kata kunci ; bawang merah, ekstrak kulit pisang, hasil, pertumbuhan, pupuk kandang ayam.

\begin{abstract}
This study aims to determine the effect of giving Kepok banana peel extract and chicken manure on the growth and yield of shallot plants. This research was conducted in the experimental field of the Main Seed Center, Jalan Karya Jaya No. 22 f Medan Johor District with an altitude of +27 masl. Data analysis used factorial randomized block design (RBD) with 2 factors, the first factor was Kepok banana peel extract with 4 levels, namely P0: without treatment (Control), P1: $60 \mathrm{ml} /$ polybag, K2: $120 \mathrm{ml}$ / polybag, K3: $180 \mathrm{ml} /$ polybag and the second factor was giving chicken manure with 4 levels, namely K0: without treatment (Control), K1: $60 \mathrm{~g} /$ polybag, K2: $120 \mathrm{~g}$ / polybag, S3: $180 \mathrm{~g} /$ polybag. If F count is greater than $\mathrm{F}$ table $5 \%$, then a further test is carried out using the DMRT (Duncan's Multiple Range Test) at the 5\% real level. Kepok banana peel extract and the combination of banana peel extract with chicken manure did not have a significant effect. Onion plants responded to the application of chicken manure and had a significant effect on plant height, number of leaves, tuber wet weight per plot, tuber dry weight per plot and production of sample plants.
\end{abstract}

Keywords; onion, banana peel extract, yield, growth, chicken manure.

PENDAHULUAN

Bawang merah (Allium ascalonicum L.) merupakan salah satu komoditas tanaman hortikultura yang banyak dikonsumsi manusia sebagai campuran bumbu masak setelah cabe. Selain sebagai campuran bumbu masak, 
bawang merah juga dijual dalam bentuk olahan seperti ekstrak bawang merah, bubuk, minyak atsiri, bawang goreng bahkan sebagai bahan obat untuk menurunkan kadar kolesterol, gula darah, mencegah penggumpalan darah, menurunkan tekanan darah serta memperlancar aliran darah. Sebagai komoditas hortikultura yang banyak dikonsumsi masyarakat, potensi pengembangan bawang merah masih terbuka lebar tidak saja untuk kebutuhan dalam negeri tetapi juga luar negeri. Pertumbuhan dan perkembangan tanaman sangat dipengaruhi oleh pemberian pupuk dan ketersediaan unsur hara di dalam tanah (Irfan, 2013).

Bawang merah berpotensi untuk dikembangkan di Indonesia, khususnya di Provinsi Sumatera Utara bawang merah merupakan salah satu tanaman yang disukai masyarakat terutama di medan, karena mengandung aroma yang khas untuk memasak. Provinsi Sumatera Utara perluasan areal lahan untuk tanam sehingga dapat meningkatkan produksi bawang merah. Permintaan bawang merah semakin meningkat seiring dengan meningkatnya pertumbuhan manusia. Peningkatan permintaan pasar produksi bawang merah tidak hanya untuk pasar dalam negeri melainkan luar negeri juga. Kegunaan lain dari bawang merah ialah sebagai obat tradisional yang manfaatnya sudah dirasakan oleh masyarakat luas (Amin, 2018).

Produksi bawang merah Sumatera Utara (Sumut) masih sangat minim, bulan Januari 2018, produksi bawang merah hanya 1.002 ton, sementara kebutuhannya sebanyak 4.278 ton. Dengan produksi tersebut, Sumut defisit sebanyak 3.276 ton. Karena itu, untuk memenuhi kebutuhan harus memasok dari Pulau Jawa. "untuk bawang merah memang masih harus didatangkan dari Pulau Jawa khususnya dari Brebes.

Pengembangan bawang merah sudah ditingkatkan sejak tahun lalu dengan mematok luas tanam 1.500 hektar, tetapi hasilnya belum mencukupi walaupun sudah dilakukan perluasan lahan dibandingkan tahun sebelumnya tahun 2016 seluas 1.410 hektar, tahun 2015 seluas 1.334 hektar, tahun 2014 seluas 1.150 hektar dan tahun 2013 seluas 837 hektar. Pengembangan bawang merah akan tetap difokuskan tahun ini sehingga bisa mengurangi ketergantungan terhadap pasokan dari Pulau Jawa. Untuk meningkatkan hasil bawang merah dapat dengan memanfaatkan ekstrak kulit pisang kepok dan pupuk kandang ayam, karena ekstrak kulit pisang mengandung unsur hara $\mathrm{N}, \mathrm{P}, \mathrm{K}$ dan pupuk kandang ayam mempunyai kandungan nitrogen dan fosfat yang lebih tinggi dibandingkan pupuk kandang yang lain, selain itu juga pupuk kandang ayam dapat memperbaiki sifat fisik tanah dan meningkatkan aktifitas mikroorganisme dalam tanah serta menambah unsur hara pada tanah untuk kesuburan terhadap tanaman (BPS Provinsi Sumatera Utara, 2018).

Tanaman pisang merupakan tanaman bubidaya masyarakat yang sangat tumbuh subur di Indonesia. Karena limbah kulit pisang kepok dapat dimanfaatkan sebagai pupuk organik cair, yang banyak memiliki kandungan seperti, protein dan fospor, selain itu juga mengandung unsur N, P dan K (Risky, 2015). Hasil penelitian (Rambitan, 2013). Pupuk organik cair dari limbah kulit pisang kepok dapat mendukung pertumbuhan dan produksi tanaman kacang tanah. Keadaan tersebut diduga karena kandungan unsur hara mikro dan makro yang terdapat dalam kulit pisang kepok.

Pupuk kandang ayam membantu menetralkan $\mathrm{pH}$ tanah, mempertinggi porositas tanah dan secara langsung meningkatkan ketersediaan air tanah dan membantu penyerapan hara dari pupuk kimia yang ditambahkan. Pupuk kandang ayam merupakan sumber hara yang penting karena mempunyai kandungan nitrogen dan fosfat yang lebih tinggi dibandingkan pupuk kandang lainya seperti dilaporkan (Heriman, 2016). Hasil penelitian (Sipayung, 2013). Secara umum pemberian pupuk kandang ayam $120 \mathrm{~g} /$ tanaman meningkatkan pertumbuhan dan produksi bawang merah. Pemberian pupuk kandang 
ditujukan untuk memperbaiki sifat fisik tanah, menambah unsur hara tanah dan meningkatkan aktivitas mikroorganisme dalam tanah.

\section{METODE PENELITIAN}

Penelitian ini dilaksanakan di Lahan Percobaan Balai Benih Induk jl. Karya Jaya no. 22 Medan Ketinggian tempat $\pm 27 \mathrm{mdpl}$.

Bahan yang digunakan dalam penelitian ini adalah benih bawang merah varietas Bima Brebes, topsoil, ekstrak Kulit Pisang Kepok, EM-4, Pupuk kandang ayam, insektisida, Fungisida Antracol, Air dan bahan-bahan lain yang mendukung dalam penelitian ini. Alat yang digunakan dalam penelitian ini adalah cangkul, meteran, gembor, tali plastik, handsprayer, timbangan analitik, pisau, polybag ukuran $35 \times 40 \mathrm{~cm}$, bambu, kamera digital, plang, alat tulis, dan alat lain yang mendukung penelitian ini.

Penelitian ini dilakukan dengan menggunakan Rancangan Acak Kelompok (RAK) Faktorial dengan dua faktor yang diteliti, yaitu: ekstrak kulit pisang kepok dengan 4 taraf yaitu $\mathrm{P}_{0}$ : tanpa perlakuan (Kontrol), $\mathrm{P}_{1}$ : $60 \mathrm{ml} /$ polybag, $\mathrm{K}_{2}: 120$ $\mathrm{ml} /$ polybag, $\mathrm{K}_{3}: 180 \mathrm{ml} /$ polybag dan faktor kedua pemberian pupuk kandang ayam dengan 4 taraf yaitu $\mathrm{K}_{0}$ : tanpa perlakuan (Kontrol), $\mathrm{K}_{1}: 60$ g/polybag, $\mathrm{K}_{2}: 120$ g/polybag, $\mathrm{S}_{3}: 180 \mathrm{~g} /$ polybag. Jika F hitung lebih besar dari $\mathrm{F}$ tabel 5\% maka dilakukan uji lanjut dengan menggunakan uji DMRT (Duncan's Multiple Range Test) pada taraf nyata $5 \%$.

Parameter yang diukur adalah tinggi tanaman, jumlah daun, jumlah anakan, bobot basah umbi per plot, bobot kering per plot, produksi tanaman dan shoot root ratio pada bawang merah.

\section{HASIL DAN PEMBAHASAN \\ Tinggi Tanaman}

Berdasarkan hasil analisis statistik menunjukkan bahwa pemberian ekstrak kulit pisang kepok tidak berpengaruh nyata terhadap tinggi tanaman bawang, begitu pula dengan kombinasi antara ekstrak kulit pisang kepok dengan pupuk kandang ayam. Pemberian pupuk kandang ayam berpengaruh nyata terhadap tinggi tanaman bawang pada umur 2, 3, 4, 5 dan 6 MST. Tinggi tanaman bawang terhadap pemberian ekstrak kulit pisang kepok dan pupuk kandang ayam dapat dilihat pada tabel 1 .

Tabel 1. Tinggi Tanaman Bawang Merah dengan Perlakuan Ekstrak Kulit Pisang Kepok dan Pupuk Kandang Ayam Umur 2, 3, 4, 5 dan 6 MST

\begin{tabular}{cccccc}
\hline \multicolumn{5}{c}{ Umur Tanaman (MST) } \\
\hline Perlakuan & 2 & 3 & 4 & 5 & 6 \\
\hline \multicolumn{5}{c}{ Ekstrak Kulit Pisang Kepok } \\
\hline $\mathrm{P}_{0}$ & 20,23 & 26,58 & 31,83 & 36,25 & 39,64 \\
$\mathrm{P}_{1}$ & 21,42 & 27,04 & 31,79 & 35,83 & 39,92 \\
$\mathrm{P}_{2}$ & 21,25 & 26,92 & 31,96 & 36,67 & 40,94 \\
$\mathrm{P}_{3}$ & 20,98 & 26,29 & 31,56 & 35,75 & 40,51 \\
\hline \multicolumn{7}{c}{ Pupuk Kandang Ayam } \\
\hline $\mathrm{K}_{0}$ & $17,17 \mathrm{~b}$ & $22,67 \mathrm{~b}$ & $27,35 \mathrm{~b}$ & $31,50 \mathrm{~b}$ & $36,06 \mathrm{~b}$ \\
$\mathrm{~K}_{1}$ & $21,38 \mathrm{ab}$ & $26,42 \mathrm{ab}$ & $31,25 \mathrm{ab}$ & $35,50 \mathrm{ab}$ & $39,85 \mathrm{ab}$ \\
$\mathrm{K}_{2}$ & $21,73 \mathrm{ab}$ & $27,42 \mathrm{ab}$ & $33,17 \mathrm{ab}$ & $37,83 \mathrm{ab}$ & $41,33 \mathrm{ab}$ \\
$\mathrm{K}_{3}$ & $23,60 \mathrm{a}$ & $30,33 \mathrm{a}$ & $35,38 \mathrm{a}$ & $39,67 \mathrm{a}$ & $43,76 \mathrm{a}$ \\
\hline $\mathrm{P}_{0} \mathrm{~K}_{0}$ & 15,75 & 21,58 & 25,67 & 30,08 & 34,50 \\
$\mathrm{P}_{0} \mathrm{~K}_{1}$ & 19,92 & 25,50 & 31,17 & 35,50 & 39,50 \\
$\mathrm{P}_{0} \mathrm{~K}_{2}$ & 22,58 & 28,42 & 34,08 & 38,92 & 39,92 \\
$\mathrm{P}_{0} \mathrm{~K}_{3}$ & 22,67 & 30,83 & 36,42 & 40,50 & 44,63 \\
$\mathrm{P}_{1} \mathrm{~K}_{0}$ & 16,25 & 21,83 & 27,92 & 31,25 & 36,17
\end{tabular}




$\begin{array}{llllll}\mathrm{P}_{1} \mathrm{~K}_{1} & 23,00 & 27,75 & 32,08 & 36,83 & 40,92 \\ \mathrm{P}_{1} \mathrm{~K}_{2} & 22,50 & 28,58 & 33,17 & 37,17 & 40,42 \\ \mathrm{P}_{1} \mathrm{~K}_{3} & 23,92 & 30,00 & 34,00 & 38,08 & 42,17 \\ \mathrm{P}_{2} \mathrm{~K}_{0} & 19,00 & 24,17 & 27,92 & 31,92 & 36,50 \\ \mathrm{P}_{2} \mathrm{~K}_{1} & 21,17 & 26,25 & 30,92 & 35,42 & 39,83 \\ \mathrm{P}_{2} \mathrm{~K}_{2} & 21,00 & 26,50 & 33,17 & 38,33 & 42,75 \\ \mathrm{P}_{2} \mathrm{~K}_{3} & 23,83 & 30,75 & 35,83 & 41,00 & 44,67 \\ \mathrm{P}_{3} \mathrm{~K}_{0} & 17,67 & 23,08 & 27,92 & 32,75 & 37,08 \\ \mathrm{P}_{3} \mathrm{~K}_{1} & 21,42 & 26,17 & 30,83 & 34,25 & 39,14 \\ \mathrm{P}_{3} \mathrm{~K}_{2} & 20,83 & 26,17 & 32,25 & 36,92 & 42,25 \\ \mathrm{P}_{3} \mathrm{~K}_{3} & 24,00 & 29,75 & 35,25 & 39,08 & 43,58\end{array}$

Keterangan: Angka yang diikuti huruf yang tidak sama pada baris dan kolom yang sama berbeda nyata menurut Uji DMRT 5\%, sedangkan angka yang tidak bernotasi menyatakan berbeda nyata menurut Uji DMRT $5 \%$.

Pada Tabel 1 dapat dilihat bahwa tanaman tertinggi pada pemberian ekstrak kulit pisang kepok umur 6 MST adalah $\mathrm{P}_{3}$ yaitu $(40,94 \mathrm{~cm})$ dan yang terendah $\mathrm{P}_{0}$ $(39,64 \mathrm{~cm})$. Hal ini disebabkan karena kosentrasi dari ekstrak kulit pisang kepok tersebut tidak memenuhi kebutuhan hara tanaman sehingga proses pertumbuhan tinggi tanaman tidak maksimal. Menurut Wandana (2012) dijelaskan juga bahwa aktifitas ekstrak kulit pisang kepok yang diberikan dari luar dapat dipengaruhi oleh kosentrasi, umur atau fase pertumbuhan tanaman, kondisi lingkungan tempat tumbuh tanaman dan jenis tanaman.

Rataan tertinggi akibat pemberian pupuk kandang ayam pada umur umur 6 MST adalah $\mathrm{K}_{3}(43,76 \mathrm{~cm})$ yang berbeda nyata dengan $\mathrm{K}_{0}(36,06 \mathrm{~cm})$ tetapi tidak berbeda nyata dengan $K_{1}(39,85 \mathrm{~cm})$ dan $K_{2}$ $(41,33 \mathrm{~cm})$. Dengan menggunakan analisis regresi dan korelasi, hubungan pemberian pupuk kandang ayam dengan tinggi tanaman bawang merah dapat dilihat pada Gambar 1.

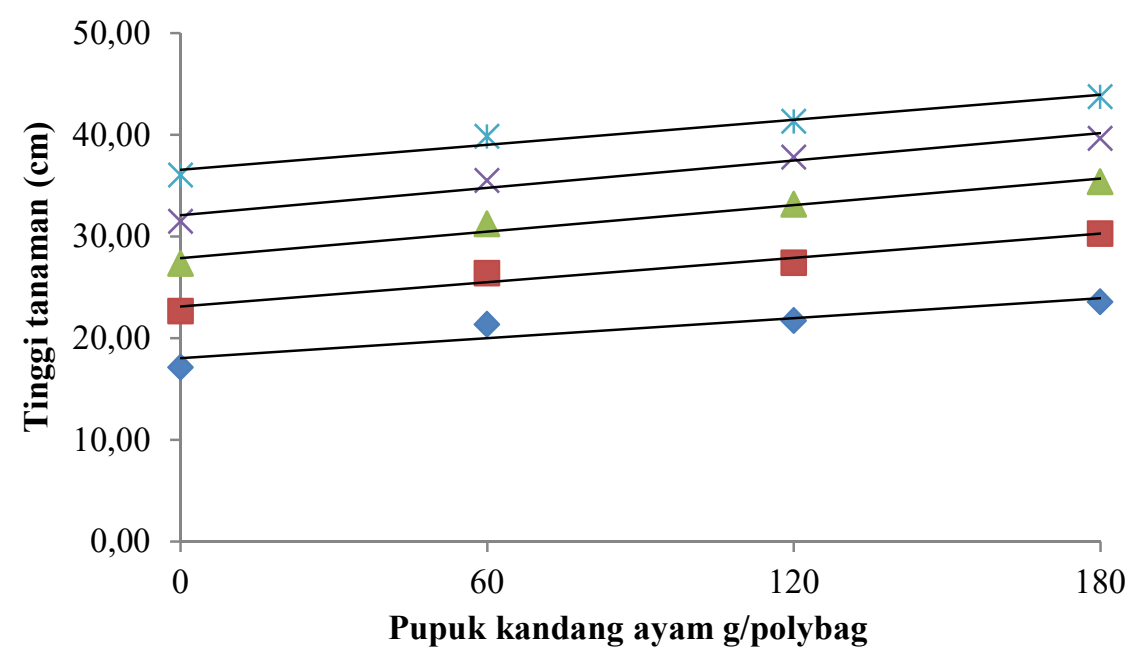

$$
\begin{gathered}
\hat{y}=36,06+0,041 x \\
r=0,96 \\
6 \mathrm{mst} \\
\hat{y}=31,50+0,044 x \\
r=0,96 \\
5 \mathrm{mst} \\
\hat{y}=27,35+0,043 \mathrm{x} \\
\mathrm{r}=0,97 \\
4 \mathrm{mst} \\
\hat{y}=22,67+0,032 \mathrm{x} \\
\mathrm{r}=0,87 \\
3 \mathrm{mst} \\
\hat{y}=17,17+0,04 \mathrm{x} \\
\mathrm{r}=0,95 \\
2 \mathrm{mst}
\end{gathered}
$$

Gambar 1. Hubungan Tinggi Tanaman Bawang Merah dengan Pemberian Pupuk Kandang Ayam 2, 3, 4, 5 Dan 6 MST

Pada Gambar 1 dapat diketahui bahwa tinggi tanaman bawang akan naik seiring dengan penambahan dosis pupuk kandang ayam. Pada umur 6 MST menunjukkan hubungan linear positif dengan persamaan regresi $(\hat{y}=36,06+$ $0,041 \mathrm{x}$ dengan nilai $\mathrm{r}=0,96)$. Hal ini disebabkan karena pemberian dosis pupuk kandang ayam pada dosis (180 g/polybag) sudah optimal, sehingga akan mengalami 
kenaikan pada parameter tinggi tanaman bawang merah. Aplikasi pupuk kandang ayam dilakukan 5 hari sebelum tanam, sehingga proses penguraian pupuk oleh tanah dengan dosis tinggi cukup lama mengakibatkan pemberian dosis yang banyak menunjukkan hasil yang tinggi dimana unsur $\mathrm{N}$ berperan dalam proses pertumbuhan vegetatif tanaman. Menurut Lingga (2008) menyatakan bahwa respon tanaman terhadap pemupukan akan meningkat jika pemberian pupuk sesuai dengan dosis waktu dan cara yang tepat.
Jumlah Daun.

Berdasarkan hasil analisis statistik menunjukkan bahwa pemberian ekstrak kulit pisang kepok dan kombinasi antara ekstrak kulit pisang kepok dengan pupuk kandang ayam tidak berpengaruh nyata terhadap parameter jumlah daun. Perlakuan pupuk kandang ayam berpengaruh nyata terhadap parameter jumlah daun umur 2 MST sampai dengan 6 MST. Jumlah daun tanaman bawang terhadap pemberian ekstrak kulit pisang kepok dan pupuk kandang ayam dapat dilihat pada Tabel 2 .

Tabel 2. Jumlah daun bawang merah dengan perlakuan ekstrak kulit pisang kepok dan pupuk kandang ayam umur 2, 3, 4, 5 dan 6 MST

\begin{tabular}{cccccc}
\hline \multicolumn{5}{c}{ Jumlah Daun (Helai) Pada Umur (MST) } \\
\hline Perlakuan & 2 & 3 & 4 & 5 & 6 \\
\hline \multicolumn{5}{c}{ Ekstrak Kulit Pisang Kepok } \\
\hline \multicolumn{5}{c}{ Ekstrak Kulit Pisang Kepok (Helai) Pada Umur (MST) } \\
\hline $\mathrm{P}_{0}$ & 12,46 & 16,44 & 21,71 & 23,75 & 25,58 \\
$\mathrm{P}_{1}$ & 12,79 & 16,46 & 22,06 & 24,06 & 25,75 \\
$\mathrm{P}_{2}$ & 14,92 & 18,48 & 23,35 & 25,69 & 27,44 \\
$\mathrm{P}_{3}$ & 13,75 & 17,21 & 21,92 & 24,23 & 26,29 \\
\hline \multicolumn{5}{c}{ Pupuk Kandang Ayam } \\
\hline $\mathrm{K}_{0}$ & $10,88 \mathrm{~b}$ & $14,00 \mathrm{~b}$ & $18,21 \mathrm{~b}$ & $20,50 \mathrm{~b}$ & $22,44 \mathrm{~b}$ \\
$\mathrm{~K}_{1}$ & $12,33 \mathrm{ab}$ & 15,98 ab & $21,02 \mathrm{ab}$ & $23,27 \mathrm{ab}$ & $24,90 \mathrm{ab}$ \\
$\mathrm{K}_{2}$ & $15,21 \mathrm{ab}$ & 19,08 ab & $24,27 \mathrm{ab}$ & $26,79 \mathrm{ab}$ & $28,33 \mathrm{ab}$ \\
$\mathrm{K}_{3}$ & $15,50 \mathrm{a}$ & $19,52 \mathrm{a}$ & $25,54 \mathrm{a}$ & $27,17 \mathrm{a}$ & $29,40 \mathrm{a}$ \\
\hline $\mathrm{P}_{0} \mathrm{~K}_{0}$ & 10,08 & 13,25 & 17,42 & 19,92 & 21,42 \\
$\mathrm{P}_{0} \mathrm{~K}_{1}$ & 11,92 & 15,58 & 21,00 & 24,08 & 25,83 \\
$\mathrm{P}_{0} \mathrm{~K}_{2}$ & 14,25 & 18,50 & 24,58 & 26,67 & 27,58 \\
$\mathrm{P}_{0} \mathrm{~K}_{3}$ & 13,58 & 18,42 & 23,83 & 24,33 & 27,50 \\
$\mathrm{P}_{1} \mathrm{~K}_{0}$ & 11,67 & 15,42 & 20,17 & 22,67 & 24,83 \\
$\mathrm{P}_{1} \mathrm{~K}_{1}$ & 10,83 & 14,25 & 19,42 & 21,08 & 22,42 \\
$\mathrm{P}_{1} \mathrm{~K}_{2}$ & 14,58 & 18,42 & 25,25 & 26,33 & 28,50 \\
$\mathrm{P}_{1} \mathrm{~K}_{3}$ & 14,08 & 17,75 & 23,42 & 26,17 & 27,25 \\
$\mathrm{P}_{2} \mathrm{~K}_{0}$ & 10,92 & 13,92 & 17,42 & 19,42 & 21,33 \\
$\mathrm{P}_{2} \mathrm{~K}_{1}$ & 14,25 & 18,25 & 24,08 & 26,67 & 27,92 \\
$\mathrm{P}_{2} \mathrm{~K}_{2}$ & 16,42 & 20,08 & 23,75 & 26,67 & 28,67 \\
$\mathrm{P}_{2} \mathrm{~K}_{3}$ & 18,08 & 21,67 & 28,17 & 30,00 & 31,83 \\
$\mathrm{P}_{3} \mathrm{~K}_{0}$ & 10,83 & 13,42 & 17,83 & 20,00 & 22,17 \\
$\mathrm{P}_{3} \mathrm{~K}_{1}$ & 12,33 & 15,83 & 19,58 & 21,25 & 23,42 \\
$\mathrm{P}_{3} \mathrm{~K}_{2}$ & 15,58 & 19,33 & 23,50 & 27,50 & 28,58 \\
$\mathrm{P}_{3} \mathrm{~K}_{3}$ & 16,25 & 20,25 & 26,75 & 28,17 & 31,00 \\
\hline
\end{tabular}

Keterangan: Angka yang diikuti huruf yang tidak sama pada kolom yang sama berbeda nyata menurut Uji DMRT 5\%, sedangkan angka yang tidak bernotasi menyatakan berbeda nyata menurut Uji DMRT $5 \%$. 
Pada Tabel 2. dapat dilihat bahwa jumlah daun tanaman bawang umur 6 MST terdapat pada perlakuan $\mathrm{P}_{2}$ yaitu $(27,44$ helai) dan terendah $\mathrm{P}_{0}$ yaitu $(25,58$ helai). Hal ini disebabkan karena pemberian ekstrak kulit pisang kepok dengan dosis 60 - $180 \mathrm{ml} /$ tanaman tidak memberikan efek atau unsur hara yang diberikan tidak dapat diserap dengan optimal. Menurut sutejo (2002), unsur hara nitrogen, fosfor dan kalium mempengaruhi perkembangan jaringan meristem yang dapat membantu mempengaruhi pertumbuhan panjang, lebar dan jumlah daun.

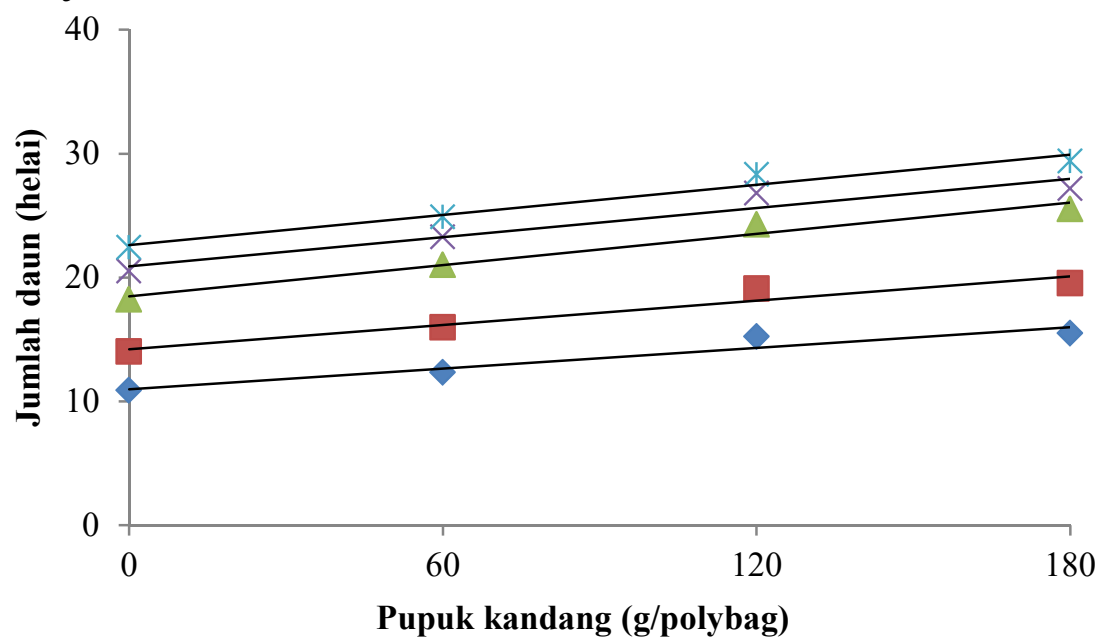

$$
\begin{gathered}
\hat{y}=22,44+0,040 x \\
r=0,96 \\
6 \text { MST } \\
\hat{y}=20,50+0,039 x \\
r=0,92 \\
5 \text { MST } \\
\hat{y}=18,210,042 x \\
=0,97 \\
4 \text { MST } \\
\hat{y}=14,00+0,032 x \\
r=0,93 \\
3 \text { MST } \\
\hat{y}=10,88+0,027 x \\
r=0,92 \\
2 \text { MST }
\end{gathered}
$$

Gambar 2. Hubungan Jumlah Daun Tanaman Bawang Merah dengan Pemberian Pupuk Kandang Ayam 2,3,4,5 dan 6 MST.

Pada Gambar 2 dapat dilihat bahwa jumlah daun tanaman bawang merah mengalami peningkatan seiring dengan bertambahnya dosis. Pada umur 6 MST menunjukan hubungan linier positif dengan persamaan regresi $(\hat{\mathrm{y}}=22,44+0,040 \mathrm{x}$ dengan $r=0,96)$. Hal ini diduga dengan dosis pupuk kandang ayam tersebut mampu menyediakan unsur esensial bagi pertumbuhan tanaman terutama unsur $\mathrm{N}$. Menurut Jumin (2008) nitrogen berfungsi untuk merangsang pertunasan dan penambahan jumlah daun. Bahwa nitrogen dalam jumlah yang cukup berperan dalam mempercepat pertumbuhan tanaman secara keseluruhan, khususnya batang dan daun. Unsur nitrogen berperan dalam pembentukan sel, jaringan dan organ tanaman. Selain itu, berfungsi sebagai bahan sintesis klorofil, protein dan asam amino.

\section{Jumlah Anakan}

Berdasarkan hasil analisis statistik menunjukkan bahwa pemberian ekstrak kulit pisang kepok dan pupuk kandang ayam, serta kombinasi antara ekstrak kulit pisang kepok dengan pupuk kandang ayam tidak berpengaruh nyata terhadap parameter jumlah anakan pada umur 2 sampai 6 MST.

Jumlah anakan tanaman bawang terhadap pemberian ekstrak kulit pisang kepok dan pupuk kandang ayam dapat dilihat pada tabel 3 . 
Tabel 3. Jumlah anakan bawang merah dengan perlakuan ekstrak kulit pisang kepok dan pupuk kandang ayam Umur 2, 3, 4, 5 dan 6 MST

\begin{tabular}{cccccc}
\hline \multirow{2}{*}{ Perlakuan } & \multicolumn{5}{c}{ Umur Tanaman (MST) } \\
\cline { 2 - 6 } & 2 & 3 & 4 & 5 \\
\hline \multicolumn{5}{c}{ Ekstrak Kulit Pisang Kepok } \\
\hline $\mathrm{P}_{0}$ & 4,94 & 5,52 & 5,52 & 5,52 & 5,52 \\
$\mathrm{P}_{1}$ & 5,10 & 5,54 & 5,54 & 5,54 & 5,54 \\
$\mathrm{P}_{2}$ & 5,02 & 5,52 & 5,52 & 5,52 & 5,52 \\
$\mathrm{P}_{3}$ & 4,71 & 5,08 & 5,08 & 5,08 & 5,08 \\
\hline \multicolumn{6}{c}{ Pupuk Kandang Ayam } \\
\hline $\mathrm{K}_{0}$ & 4,73 & 5,06 & 5,06 & 5,06 & 5,06 \\
$\mathrm{~K}_{1}$ & 4,73 & 5,50 & 5,50 & 5,50 & 5,50 \\
$\mathrm{~K}_{2}$ & 4,73 & 5,69 & 5,69 & 5,69 & 5,69 \\
$\mathrm{~K}_{3}$ & 4,73 & 5,42 & 5,42 & 5,42 & 5,42 \\
\hline $\mathrm{P}_{0} \mathrm{~K}_{0}$ & 4,42 & 4,67 & 4,67 & 4,67 & 4,67 \\
$\mathrm{P}_{0} \mathrm{~K}_{1}$ & 5,08 & 6,00 & 6,00 & 6,00 & 6,00 \\
$\mathrm{P}_{0} \mathrm{~K}_{2}$ & 5,17 & 5,75 & 5,75 & 5,75 & 5,75 \\
$\mathrm{P}_{0} \mathrm{~K}_{3}$ & 5,08 & 5,67 & 5,67 & 5,67 & 5,67 \\
$\mathrm{P}_{1} \mathrm{~K}_{0}$ & 4,83 & 5,33 & 5,33 & 5,33 & 5,33 \\
$\mathrm{P}_{1} \mathrm{~K}_{1}$ & 5,17 & 5,42 & 5,42 & 5,42 & 5,42 \\
$\mathrm{P}_{1} \mathrm{~K}_{2}$ & 5,33 & 5,92 & 5,92 & 5,92 & 5,92 \\
$\mathrm{P}_{1} \mathrm{~K}_{3}$ & 5,08 & 5,50 & 5,50 & 5,50 & 5,50 \\
$\mathrm{P}_{2} \mathrm{~K}_{0}$ & 5,00 & 5,17 & 5,17 & 5,17 & 5,17 \\
$\mathrm{P}_{2} \mathrm{~K}_{1}$ & 5,08 & 5,75 & 5,75 & 5,75 & 5,75 \\
$\mathrm{P}_{2} \mathrm{~K}_{2}$ & 5,25 & 5,75 & 5,75 & 5,75 & 5,75 \\
$\mathrm{P}_{2} \mathrm{~K}_{3}$ & 4,75 & 5,42 & 5,42 & 5,42 & 5,42 \\
$\mathrm{P}_{3} \mathrm{~K}_{0}$ & 4,67 & 5,08 & 5,08 & 5,08 & 5,08 \\
$\mathrm{P}_{3} \mathrm{~K}_{1}$ & 4,58 & 4,83 & 4,83 & 4,83 & 4,83 \\
$\mathrm{P}_{3} \mathrm{~K}_{2}$ & 4,83 & 5,33 & 5,33 & 5,33 & 5,33 \\
$\mathrm{P}_{3} \mathrm{~K}_{3}$ & 4,75 & 5,08 & 5,08 & 5,08 & 5,08 \\
\hline & \multicolumn{1}{c}{} & & &
\end{tabular}

Berdasarkan Tabel 3. dapat dilihat bahwa pada umur 6 MST jumlah anakan dengan rataan tertinggi akibat pemberian ekstrak kulit pisang kepok terdapat pada perlakuan $\mathrm{P}_{1}(5,54)$ dan terendah $\mathrm{P}_{3}(5,08)$. Hal ini disebabkan perlakuan tersebut dimanfaatkan oleh tanaman dalam pertumbuhan dan perkembangan tanaman, tetapi tidak berdampak terhadap pembentukan jumlah anakan dikarenaka pembentukan jumlah anakan ditentukan oleh jumlah tunas lateral yang terdapat pada bibit umbi bawang merah. Tunas laterral kemudian membentuk umbi baru. Menurut Husna (2017) bahwa pertumbuhan tunas membentuk anakan, bibit memanfaatkan cadangan makanan yang terdapat pada umbi bibit. Pertumbuhan selanjutnya (pembesaran umbi yang terbentuk) sebagai penentu produksi dibutukan lingkungan tumbuh yang optimal diantaranya media tumbuh yang baik dan unsur hara yang dibutuhkan tersedia.

Jumlah anakan dengan rataan tertinggi terhadap pemberian pupuk kandang ayam umur umur 6 MST terdapat pada perlakuan $\mathrm{K}_{2}(5,69)$ dan yang terendah $\mathrm{K}_{0}$ (5,06). Hal ini disebabkan karena kurangnya unsur $\mathrm{K}$ dalam pupuk kandang ayam, dimana kalium yang cukup tinggi berperan sebagai pembentukan umbi bawang merah. Para peneliti menyatakan pada pertumbuhannya bawang merah memerlukan unsur kalium yang cukup tinggi dalam pembetukan umbi. Kalium dalam tanaman sangat penting yaitu berperan sebagai kofaktor enzim dalam proses metabilisme tanaman.

\section{Bobot Basah Umbi per Plot}

Berdasarkan hasil analisis statistik menunjukkan bahwa pemberian ekstrak kulit pisang kepok tidak berpengaruh nyata terhadap bobot basah umbi per plot, begitu pula dengan kombinasi antara ekstrak kulit pisang kepok dengan pupuk kandang ayam. Pemberian pupuk kandang ayam berpengaruh nyata terhadap bobot basah umbi per plot. Bobot basah umbi per plot terhadap pemberian ekstrak kulit pisang kepok dan pupuk kandang ayam dapat dilihat pada Tabel 4. 
Tabel 4. Bobot basah umbi per plot bawang merah dengan perlakuan ekstrak kulit pisang kepok dan pupuk kandang ayam

\begin{tabular}{|c|c|c|c|c|c|}
\hline \multirow{3}{*}{$\begin{array}{l}\text { Ekstrak kulit } \\
\text { pisang kepok }\end{array}$} & \multicolumn{4}{|c|}{ Pupuk kandang ayam } & \multirow{2}{*}{ Rataan } \\
\hline & $\mathrm{K}_{0}$ & $\mathrm{~K}_{1}$ & $\mathrm{~K}_{2}$ & $\mathrm{~K}_{3}$ & \\
\hline & & & $\ldots .(\mathrm{g})$ & & \\
\hline $\mathrm{P}_{0}$ & 216,67 & 265,33 & 270,00 & 300,00 & 263,00 \\
\hline $\mathrm{P}_{1}$ & 221,67 & 257,33 & 275,00 & 320,00 & 268,50 \\
\hline $\mathrm{P}_{2}$ & 223,33 & 273,33 & 275,00 & 334,33 & 276,50 \\
\hline $\mathrm{P}_{3}$ & 235,00 & 253,33 & 288,33 & 305,00 & 270,42 \\
\hline Rataan & $224,17 \mathrm{c}$ & $262,33 \mathrm{~b}$ & $277,08 \mathrm{~b}$ & $314,83 \mathrm{a}$ & \\
\hline
\end{tabular}

Keterangan: Angka yang diikuti huruf yang tidak sama pada kolom yang sama berbeda nyata menurut Uji DMRT 5\%

Tabel 4 menunjukkan bahwa perlakuan ekstrak kulit pisang kepok tidak berpengaruh nyata pada parameter bobot basah umbi per plot namun hasil tertinggi terdapat pada perlakuan $\mathrm{P}_{2}(27650)$ dan terendah $\mathrm{P}_{0}(263,00)$. Hal ini dikarenakan bahwa pemberian ekstrak kulit pisang kapok hanya sedikit yang dapat diserap oleh tanaman. Menurut Hakim (2012) pemberian ekstrak kulit pisang ke dalam tanah hanya berpengaruh sedikit pada produksi tanaman tetapi dapat mensuplai bahan organik dan nitrogen didalam tanah serta memperbaiki sifat fisik tanah. Tetapi dalam hal ekstrak kulit pisang tersebut belum dapat menyediakan kebutuhan hara untuk tanaman bawang merah karena ekstrak kulit pisang yang diberikan dalam bentuk organik belum tentu tersedia seluruhnya bagi tanaman.

Rataan tertinggi untuk bobot basah umbi per plot terhadap pemberian pupuk kandang ayam terdapat pada perlakuan $\mathrm{K}_{3}$ (180 g/polybag) yaitu $314,83 \mathrm{~g}$ yang berbeda nyata dengan $\mathrm{K}_{0}$ (kontrol) yaitu $224,17 \mathrm{~g}$ tetapi tidak berbeda nyata dengan $\mathrm{K}_{1}\left(60 \mathrm{~g} /\right.$ polybag) yaitu $262,33 \mathrm{~g}$ dan $\mathrm{K}_{2}$ (120 g/polybag) yaitu 277,08 g. Hubungan bobot basah per plot tanaman bawang merah dengan pemberian pupuk kandang dapat dilihat pada gambar 3 .

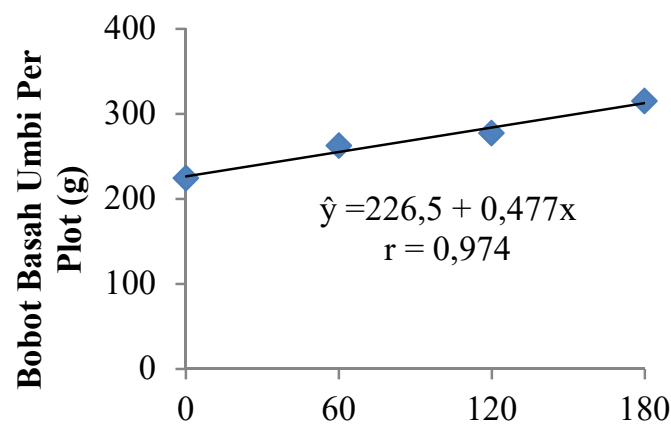

Pupuk Kandang Ayam (g/polybag)

Gambar 3. Hubungan Bobot Basah Umbi Per Plot dengan Pemberian Pupuk Kandang Ayam

Pada Gambar 3 dapat dilihat bahwa bobot basah per plot tanaman bawang merah mengalami peningkatan seiring dengan bertambahnya dosis pupuk kandang ayam yang menunjukan hubungan linier positif dengan persamaan $\hat{y}=226,5+$ 28.67x dengan nilai $r=0,974$. Hal ini disebabkan karena dengan semakin banyak dosis yang diberikan maka semakin banyak unsur hara yang tersedia oleh tanaman terutama pada unsur hara P. Dimana unsur hara $\mathrm{P}$ berfungsi sebagai perangsang pembentukan bunga dan buah sehingga dapat meningkatkan produksi tanaman bawang. Hal ini sesuai dengan pendapat Sianturi (2008) menyatakan bahwa fosfor merangsang pembentukan bunga, buah dan biji bahkan mampu mempercepat pemaskan buah dan menjadi lebih bernas. Pemupukan fosfor sangat diperlukan oleh tanaman untuk membantu fase generatif sehingga 
menghasilkan produksi yang optimal bagi tanaman bawang.

\section{Bobot Kering Umbi per Plot}

Berdasarkan hasil analisis statistik menunjukkan bahwa pemberian ekstrak kulit pisang kepok tidak berpengaruh nyata terhadap bobot kering umbi per plot, begitu pula dengan kombinasi antara ekstrak kulit

Tabel 5. Bobot kering umbi per plot bawang merah dengan perlakuan ekstrak kulit pisang kepok dan pupuk kandang ayam

\begin{tabular}{|c|c|c|c|c|c|}
\hline \multirow{2}{*}{$\begin{array}{l}\text { Ekstrak kulit } \\
\text { pisang kepok }\end{array}$} & \multicolumn{4}{|c|}{ Pupuk kandang ayam } & \multirow{2}{*}{ Rataan } \\
\hline & $\mathrm{K}_{0}$ & $\mathrm{~K}_{1}$ & $\mathrm{~K}_{2}$ & $\mathrm{~K}_{3}$ & \\
\hline & & $\ldots$ & $\ldots .(\mathrm{g})$ & & \\
\hline $\mathrm{P}_{0}$ & 115,33 & 161,00 & 168,33 & 196,00 & 160,17 \\
\hline $\mathrm{P}_{1}$ & 117,67 & 154,33 & 172,00 & 217,67 & 165,42 \\
\hline $\mathrm{P}_{2}$ & 121,33 & 171,33 & 171,00 & 231,33 & 173,75 \\
\hline $\mathrm{P}_{3}$ & 132,00 & 150,33 & 185,33 & 271,00 & 184,67 \\
\hline
\end{tabular}

Keterangan: Angka yang diikuti huruf yang tidak sama pada kolom yang sama berbeda nyata menurut Uji DMRT 5\%

Berdasarkan Tabel 5 dapat dilihat bahwa bobot kering umbi per plot dengan pemberian ekstrak kulit pisang kepok rataan tertinggi terdapat pada $\mathrm{P}_{3}(184,67)$ dan terendah $\mathrm{P}_{0}(160,17)$. Hal ini dikarenakan pemberian pupuk yang terlalu sering dapat menyebabkan pemborosan pupuk dan penyerapan pupuk menjadi tidak efektif. Menurut Wibowo (2007) bahwa waktu aplikasi juga menentukan pertumbuhan tanaman. Berbedanya waktu pemberian akan memberikan hasil yang tidak sesuai dengan pertumbuhan tanaman. Pemberian pupuk dengan interval waktu yang terlalu sering dapat menyebabkan konsumsi mewah, sehingga menyababkan pemborosan pupuk.

Hasil terbaik pemberian pupuk kandang ayam terhadap bobot kering umbi per plot terdapat pada perlakuan $\mathrm{K}_{3}(180$ g/polybag) yaitu $229,00 \mathrm{~g}$ yang berbeda nyata dengan perlakuan $\mathrm{K}_{0}$ (kontrol) yaitu $121,58 \mathrm{~g}$ tetapi tidak berbeda nyata dengan perlakuan $\mathrm{K}_{1}(60 \mathrm{~g} / \mathrm{polybag})$ yaitu $159,25 \mathrm{~g}$. Hubungan bobot kering umbi per plot tanaman bawang merah terhadap perlakuan pupuk kandang ayam dapat dilihat pada gambar 4. pisang kepok dengan pupuk kandang ayam. Pemberian pupuk kandang ayam berpengaruh nyata terhadap bobot kering umbi per plot. Bobot kering umbi per plot terhadap pemberian ekstrak kulit pisang kepok dan pupuk kandang ayam dapat dilihat pada tabel 5 .

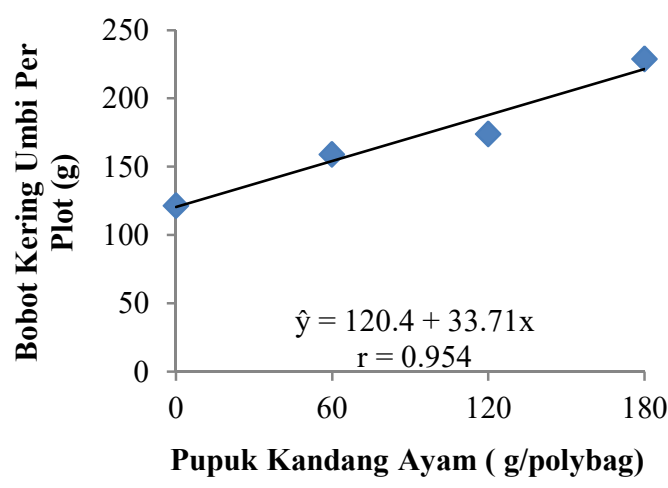

Gambar 4. Hubungan Bobot Kering Umbi Per Plot Dengan Pemberian Pupuk Kandang Ayam

Dari Gambar 5 dapat dilihat bahwa bobot kering per plot tanaman bawang merah mengalami peningkatan seiring dengan penambahan dosis pada pupuk kandang ayam menunjukkan hubungan linier positif dengan persamaan regresi $\hat{y}=$ $120,4+0,561 x$ dengan nilai $r=0,954$. Hal ini disebabkan karena pupuk kandang ayam mengandung banyak unsur hara seperti $\mathrm{N}$, $\mathrm{P}$ dan $\mathrm{K}$ yang dapat mempercepat penguraian unsur hara untuk dapat di serap oleh akar sehingga dapat memenuhi dari kebutuhan hara terhadap perkembangan dan produksi umbi bawang merah. Hal ini sesuai dengan pendapat Suryana (2008) menyatakan bahwa suatu tanaman akan 
tumbuh dan berkembang dengan subur apabila unsur hara yang dibutuhkan ada dan tersedia cukup serta ada dalam bentuk yang sesuai untuk diserap oleh bulu - bulu akar.

\section{Produksi Per sampel}

Berdasarkan hasil analisis statistik menunjukkan bahwa pemberian ekstrak kulit pisang kepok tidak berpengaruh nyata terhadap paramater produksi per sampel begitu pula dengan kombinasi antara ekstrak kulit pisang kepok dengan pupuk kandang ayam. Pemberian pupuk kandang ayam berpengaruh nyata terhadap produksi per sampel. Produksi per sampel terhadap pemberian ekstrak kulit pisang kepok dan pupuk kandang ayam dapat dilihat pada tabel 6 .

Tabel 6. Produksi tanaman per sampel bawang merah dengan perlakuan ekstrak kulit pisang kepok dan pupuk kandang ayam

\begin{tabular}{|c|c|c|c|c|c|}
\hline \multirow{3}{*}{$\begin{array}{c}\text { Ekstrak } \\
\text { Kulit } \\
\text { Pisang } \\
\text { Kepok }\end{array}$} & \multicolumn{4}{|c|}{ Pupuk Kandang Ayam } & \multirow{3}{*}{ Rataan } \\
\hline & $\mathrm{K}_{0}$ & $\mathrm{~K}_{1}$ & $\mathrm{~K}_{2}$ & $\mathrm{~K}_{3}$ & \\
\hline & & 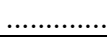 & $\ldots(\mathrm{g}) .$. & ............... & \\
\hline $\mathrm{P}_{0}$ & 36.08 & 44.08 & 45.33 & 50.08 & 43.90 \\
\hline $\mathrm{P}_{1}$ & 36.67 & 44.17 & 45.00 & 54.33 & 45.04 \\
\hline $\mathrm{P}_{2}$ & 37.58 & 47.17 & 51.83 & 55.83 & 48.10 \\
\hline $\mathrm{P}_{3}$ & 39.17 & 42.58 & 48.33 & 52.33 & 45.60 \\
\hline Rataan & $37.38 \mathrm{~b}$ & $44.50 \mathrm{ab}$ & $47.63 \mathrm{ab}$ & $53.15 \mathrm{a}$ & \\
\hline
\end{tabular}

Pada Tabel 6 dapat dilihat bahwa hasil terbanyak produksi per sampel terhadap pemberian ekstrak kulit pisang kepok terdapat pada $\mathrm{P}_{2}(48.10)$ dan terendah $\mathrm{P}_{0}$ (43.90). Hal ini disebabkan karena ekstrak kulit pisang pada umumnya dalam reaksinya membutuhkan waktu yang lebih lama dan dalam jumlah yang cukup besar. Hal ini sesuai dengan literatur Darlina et al., (2016) yang menyatakan bahwa ekstrak kulit pisang mempunyai komposisi kandungan unsur hara yang lengkap, tetapi setiap jenis unsur hara tersebut rendah.

Produksi per sampel dengan rataan tertinggi terhadap pemberian pupuk kandang ayam terdapat pada perlakuan $\mathrm{K}_{3}$
(180 g/polybag) yaitu 53,15 g yang berbeda nyata dengan perlakuan $\mathrm{K}_{0}$ (kontrol) yaitu 37,38 g tetapi tidak berbeda nyata dengan perlakuan $\mathrm{K}_{1}(60 \mathrm{~g} /$ polybag) yaitu $44,50 \mathrm{~g}$ dan perlakuan $\mathrm{K}_{2} \quad(120 \mathrm{~g} /$ polybag$)$. Hubungan produksi per sampel tanaman bawang merah dengan pemberian pupuk kandang ayam dapat dilihat pada gambar 5 .

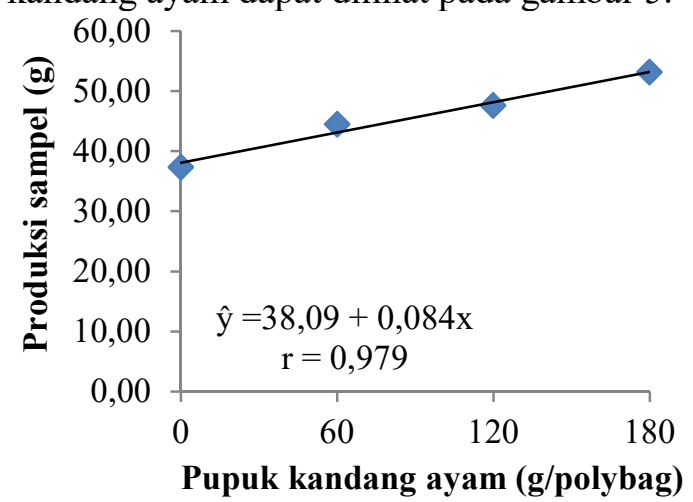

Gambar 5. Hubungan Produksi Tanaman per Sampel dengan Pemberian Pupuk Kandang Ayam

Pada Gambar 6 dapat dilihat bahwa produksi tanaman bawang merah mengalami peningkatan seiring dengan penambahan dosis pada pupuk kandang ayam dan menunjukkan hubungan linier positif dengan persamaan regresi $(\hat{y}=38,09$ $+0,084 \mathrm{x}$ dengan nilai $\mathrm{r}=0,979)$. Hal ini disebabkan karena kandungan unsur hara terutama unsur $\mathrm{P}$ didalam pupuk kandang ayam sudah sesuai sehingga dengan dosis $180 \mathrm{~g} /$ polybag sudah mampu terserap oleh tanaman. Hal ini sesuai dengan pendapat Sauwibi et al., (2011) menyatakan bahwa tanaman dapat tumbuh dan berproduksi dengan sempurna bila unsur hara yang diperlukan mencukupi. Selain itu kadar air yang seimbang di dalam tanah juga membantu penyerapan unsur hara melalui akar tanaman sehingga unsur hara mudah terserap. Suatu tanaman akan tumbuh dengan baik bila hara yang dibutuhkan cukup tersedia dalam bentuk yang mudah diserap oleh perakaran tanaman.

\section{Shoot Root Ratio}

Berdasarkan hasil analisis statistik menunjukkan bahwa pemberian ekstrak kulit pisang kepok dan pupuk kandang ayam tidak berpengaruh nyata terhadap 
paramater shoot root ratio. Data pengamatan dan sidik ragamnya dapat dilihat pada lampiran

Tabel 7. Shoot root ratio bawang merah dengan perlakuan ekstrak kulit pisang kepok dan pupuk kandang ayam

\begin{tabular}{ccccccc}
\hline \multirow{2}{*}{$\begin{array}{c}\text { Ekstrak Kulit } \\
\text { Pisang Kepok }\end{array}$} & \multicolumn{5}{c}{ Pupuk Kandang Ayam } & Rataan \\
\cline { 2 - 5 } & $\mathrm{K}_{0}$ & $\mathrm{~K}_{1}$ & $\mathrm{~K}_{2}$ & $\mathrm{~K}_{3}$ & \\
\hline $\mathrm{P}_{0}$ & 0.07 & 0.07 & 0.07 & 0.08 & 0.07 \\
$\mathrm{P}_{1}$ & 0.06 & 0.06 & 0.07 & 0.07 & 0.06 \\
$\mathrm{P}_{2}$ & 0.06 & 0.06 & 0.06 & 0.05 & 0.06 \\
$\mathrm{P}_{3}$ & 0.06 & 0.06 & 0.06 & 0.06 & 0.06 \\
\hline Rataan & 0.06 & 0.06 & 0.06 & 0.06 & \\
\hline
\end{tabular}

Berdasarkan Tabel 7. dapat dilihat produksi pertanaman dengan rataan tertinggi terhadap pemberian ekstrak kulit pisang kepok terdapat pada perlakuan $\mathrm{P}_{0}$ (tanpa perlakuan) dan terendah pada perlakuan $\mathrm{P}_{2}(120 \mathrm{ml} /$ polybag $)$ dan $\mathrm{P}_{3}(180$ $\mathrm{ml} /$ polybag) sedangkan terhadap pemberian pupuk kandang ayam tidak ada terlihat perbedaan. Parameter Shoot Root Ratio berpengaruh tidak nyata terhadap semua perlakuan. Hal ini diduga pertumbuhan suatu tanaman diikuti dengan pertumbuhan lainnya dimana pertumbuhan daun akan meningkat apabila pekembangan akar juga meningkat. Hal ini sesuai dengan pendapat Lingga (2006), menyatakan bahwa perkembangan akar sangat dipengaruhi oleh struktur tanah, air dan drainase di dalam tanah yang keadaannya sangat tergantung pada bahan organik tanah, perakaran tanaman berkembang dengan baik maka pertumbuhan bagian tanaman lainnya juga akan baik pula karena akar mampu menyerap air dan unsur hara yang dibutuhkan oleh tanaman.

\section{KESIMPULAN}

Berdasarkan hasil penelitian yang telah dilakukan menunjukkan bahwa pemberian ekstrak kulit pisang kepok tidak berpengaruh nyata terhadap pertumbuhan dan hasil bawang merah. Pupuk kandang ayam berpengaruh nyata terhadap tinggi tanaman, jumlah daun, bobot basah umbi per plot, bobot kering umbi per plot dan produksi tanaman sampel. Kombinasi perlakuan ekstrak kulit pisang dengan pupuk kandang ayam tidak memberikan interaksi terhadap semua parameter pertumbuhan dan hasil bawang merah.

\section{DAFTAR PUSTAKA}

Amin, H. 2018. Respon Pertumbuhan dan Produksi Bawang Merah (Allium $\begin{array}{lll}\text { ascalonicum } & \text { L.) Terhadap }\end{array}$ Pemberian Pupuk NPK dan Kompos Kulit Buah Kopi. Fakultas pertanian USU Medan. Jurnal Online Agroteknologi Vol. 1 No. 3. ISSN No. 2337-6597.

BPS Provinsi Sumatera Utara. 2018. Produksi Padi dan Palawija Sumatera Utara Angka Sumatera Utara Tahun 2015. Berita Resmi Statistik Provinsi Sumatra Utara. No. 17/03/12/Thn. XIX. 01 Maret 2016.

Darliana. Hasanuddin \& Rahmatan, $H$. 2016. Penyiraman pada Air Kelapa (Cocos nucifera L.) Terhadap Pertumbuhan Vegetatif Lada (Piper nigrum L). Jurnal Ilmiah Mahasiswa Pendidikan Biologi, Volume 1, Issue 1, Agustus 2016 hal 20-28.

Heriman, A. 2016. Pengaruh Pemberian Beberapa Dosis Pupuk Kandang Ayam dan Variasi Jarak Tanam Terhadap Pertumbuhan dan Hasil Bawang Merah (Allium $\begin{array}{lll}\text { ascalonicum } & \text { L.). } & \text { Fakultas }\end{array}$ Pertanian. Universitas Andalas.

Irfan, M. 2013. Respon Bawang Merah (Alllium ascalonicul L.) Terhadap Zat Pengatur Tumbuh dan Unsur Hara. Fakultas Pertanian dan Peternakan UIN Suska Riau. Jurnal Agroteknologi Vol. 3 No. 2.

Jumin, H.B. 2008. Agronomi. PT. Raja Grafindo Persada, Jakarta.

Montgomery, D.C. 2006. Design and analysis of Experiments. New York: John Wiley \& Sons.

Rambitan, V.M. 2013. Pengaruh Pupuk Kompos Cair Kulit Pisang Kepok atau (Musa paradisiaca L.) Terhadap Pertumbuhan dan Hasil 
Tanaman Kacang Tanah (Arachis hypogeal L.) Sebagai Penunjang Praktikum Fisiologi Tumbuhan. FKIP Universitas Mulawarnan Samarinda, Kalimantan Timur. Jurnal edubio Tropoka,

Sauwibi., Ali, D., Maryono, M \& Hendrayana, F. 2011. Pemanfaatan Limbah Organik Untuk Kompos. Penebar Swadaya. Jakarta.

Sianturi. D. 2008. Uji Kandungan Fosfat Sebagai P2O5 Dalam Berbagai
Merek Pupuk Fosfat Komersil Secara Spektrofotometri. Skripsi. Medan: Universitas Sumatera Utara.

Suryana, N K. 2008. Pengaruh Naungan dan Dosis Pupuk Kotoran Ayam.

Tjitrosoepomo, G. 2010. Taksonomi Umum. Yogyakarta. Gajah Mada University press. 149 halaman.

Wibowo, S. 2007. Budidaya Bawang Merah. Penebar Swadaya. Jakarta. 212. halaman. 